\title{
HUBUNGAN KEBISINGAN DENGAN PENINGKATAN KADAR GLUKOSA DARAH SEWAKTU PADA MENCIT Indra Setiawan*
}

\begin{abstract}
Abstrak
Kebisingan merupakan masalah utama kesehatan kerja dan dapat menimbulkan dampak gangguan kesehatan. Eksperimental dan rancangan penelitian yang digunakan adalab the pre test and post test control group design untuk. mengetabui perbedaan lama paparan kebisingan intensitas 90 dB pada peningkatan kadar glukosa darah sewaktu pada mencit (Mus Musculus) jantan. Kebisingan dengan lama 140 menit (mean $=57.333)$ menunjuk.kan rata-rata gula darah yang tinggi kemudian diikuti kebisingan 125 menit (mean = 33.833), kebisingan 110 menit (mean = 20.00), dan yang menunjuk.kan rata-rata gula darah yang paling rendah adalab kontrol (mean $=5.833)$. Ada bubungan lama paparan kebisingan 90 dB selama 110 menit, 125 menit, dan 140 menit dengan peningkatan kadar glukosa darah sewaktu pada mencit (Mus musculus) jantan dan Ada perbedaan lama paparan kebisingan intensitas 90 dB pada peningkatan kadar glukosa darah suatu mencit (Mus musculus) jantan.
\end{abstract}

\section{PENDAHULUAN}

Kemajuan peradaban telah menggeser perkembangan industri ke arah penggunaan mesinmesin, alat-alat transportasi berat, dan lain sebagainya. Akibatnya kebisingan makin dirasakan mengganggu dan dapat memberikan dampak pada kesehatan (Novi, 2004).

Di negara-negara industri, bising merupakan masalah utama kesehatan kerja. Menurut WHO (1995), diperkirakan hampir 14\% dari total tenaga kerja negara industri terpapar bising melebihi $90 \mathrm{~dB}$ di tempat kerjanya. Diperkirakan lebih dari 20 juta orang di Amerika terpapar bising $85 \mathrm{~dB}$ atau lebih (Roestam, 2004).

Kebisingan ini sangat mempengaruhi kesehatan manusia yang dapat berakibat pada gangguan keseimbangan, pendengaran dan non pendengaran. Gangguan keseimbangan akibat kebisingan dapat menyebabkan kesan berjalan di ruang angkasa atau melayang, yang dapat menimbulkan gangguan fisiologis berupa kepala pusing (vertigo) atau mual-mual (Roestam, 2004). Pengaruh bising pada pendengaran dapat diklasifikasikan sebagai trauma akustik, ketulian sementara dan ketulian permanen. Pengaruh bising pada non pendengaran diantaranya penyempitan pembuluh darah kecil di lengan dan tungkai, peningkatan kolesterol darah, serta pengaruh pada sistem endokrin (Stephens, Rood, 1978).

\footnotetext{
* Staff Pengajar Pada Fakultas Kedokteran

Universitas Mubammadiyah Malang
}

Pengaruh kebisingan terhadap non pendengaran menyebabkan stress dan emosi, yang menimbulkan gangguan psychosomatic. Dan jika berlanjut akan mengakibatkan kelainan fisik. Stressor akan menyebabkan peningkatan corticotropin releasing factor (CRF) hipotalamus, yang memicu aktivitas bypotalamic-pituitary-adrenocortical axis (HPA axis) yang pada akhirnya meningkatkan kadar kortisol dan aldosteron (Lang, 2000).

Peningkatan kortisol juga akan merangsang terjadinya glukoneogenesis. Konsentrasi glukosa darah perlu di kontrol karena sangat berpengaruh terhadap tekanan osmotik dalam cairan extraselular, dan menimbulkan diuresis osmotik oleh ginjal, yang dapat mengurangi jumlah cairan tubuh dan elektrolit. (Guyton, 1997). Oleh karena itu, peneliti melakukan penelitian pengaruh kebisingan intensitas tinggi terhadap mencit (Mus musculus) jantan, dengan menentukan perubahan pada kadar glukosa darah sewaktu.

\section{METODE PENELITIAN}

Penelitian ini merupakan penelitian eksperimental dan rancangan penelitian yang digunakan adalah the pre test and post test control group design untuk mengetahui perbedaan lama paparan kebisingan intensitas $90 \mathrm{~dB}$ pada peningkatan kadar glukosa darah sewaktu pada mencit (Mus Musculus) jantan yang dibagi menjadi 4 kelompok perlakuan secara simple random samplingdan setiap kelompok 6 mencit. Kelompok 1 tanpa paparan bising, 
kelompok 2 dipapar bising dengan intensitas 90 dB selama 110 menit per hari, kelompok 3 dipapar bising dengan intensitas $90 \mathrm{~dB}$ selama 125 menit per hari, bising dengan intensitas $90 \mathrm{~dB}$ selama 140 menit per hari. Semua selama 7 hari berturut-turut. Glukosa darah di ukur sebelum dan sesudah paparan 7 hari.

\section{HASIL PENELITIAN DAN ANALISA DATA}

Hasil pengukuran glukosa darah sebelum dan sesudah paparan kebisingan dengan intensitas $90 \mathrm{~dB}$ selama 7 hari serta peningkatan glukosa darah yang terjadi dapat dilihat pada tabel di bawah
Peningkatan glukosa darah merupakan selisih kadar glukosa darah post-test dengan kadar glukosa darah pre-test. setelah diperoleh data peningkatan glukosa darah, kemudian dilakukan perbandingan peningkatan kadar glukosa darah pada tiap-tiap kelompok paparan

Setelah diperoleh data peningkatan glukosa darah dan perbandingan peningkatan kadar glukosa darah pada tiap-tiap kelompok pakaran kebisingan, kemudian dilakukan analisa dengan menggunakan uji anova dan korelasi-regresi untuk membuktikan hipotesa penelitian ini.

Tabel. Peningkatan Gula Darah Sewaktu setelah paparan bising

\begin{tabular}{|c|c|c|c|}
\hline Kelompok & $\begin{array}{l}\text { Gula darah Sewaktu } \\
\text { Pre test }(\mathrm{mg} / \mathrm{dl})\end{array}$ & $\begin{array}{l}\text { Gula darah Sewaktu } \\
\text { Post test }(\mathrm{mg} / \mathrm{dl})\end{array}$ & $\begin{array}{c}\text { Peningkatan Gula } \\
\text { Darah Sewaktu }\end{array}$ \\
\hline \multicolumn{4}{|l|}{ Kontrol } \\
\hline Mencit 1 & 108 & 89 & -19 \\
\hline Mencit 2 & 99 & 114 & 15 \\
\hline Mencit 3 & 75 & 70 & -5 \\
\hline Mencit 4 & 107 & 98 & -9 \\
\hline Mencit 5 & 120 & 112 & -8 \\
\hline Mencit 6 & 86 & 77 & -9 \\
\hline \multicolumn{4}{|c|}{ Paparan 110 menit } \\
\hline Mencit 7 & 87 & 98 & 11 \\
\hline Mencit 8 & 80 & 157 & 77 \\
\hline Mencit 9 & 100 & 127 & 27 \\
\hline Mencit 10 & 113 & 132 & 19 \\
\hline Mencit 11 & 141 & 110 & -31 \\
\hline Mencit 12 & 81 & 98 & 17 \\
\hline \multicolumn{4}{|c|}{ Paparan 125 menit } \\
\hline Mencit 13 & 129 & 167 & 38 \\
\hline Mencit 14 & 113 & 163 & 50 \\
\hline Mencit 15 & 100 & 147 & 47 \\
\hline Mencit 16 & 109 & 138 & 29 \\
\hline Mencit 17 & 98 & 118 & 20 \\
\hline Mencit 18 & 77 & 96 & 19 \\
\hline \multicolumn{4}{|c|}{ Paparan 140 menit } \\
\hline Mencit 19 & 153 & 207 & 54 \\
\hline Mencit 20 & 112 & 167 & 55 \\
\hline Mencit 21 & 96 & 160 & 64 \\
\hline Mencit 22 & 131 & 189 & 58 \\
\hline Mencit 23 & 110 & 172 & 62 \\
\hline Mencit 24 & 103 & 154 & 51 \\
\hline
\end{tabular}


Gambar Plot Respon Kebisingan terhadap glukosa Darah Sewaktu

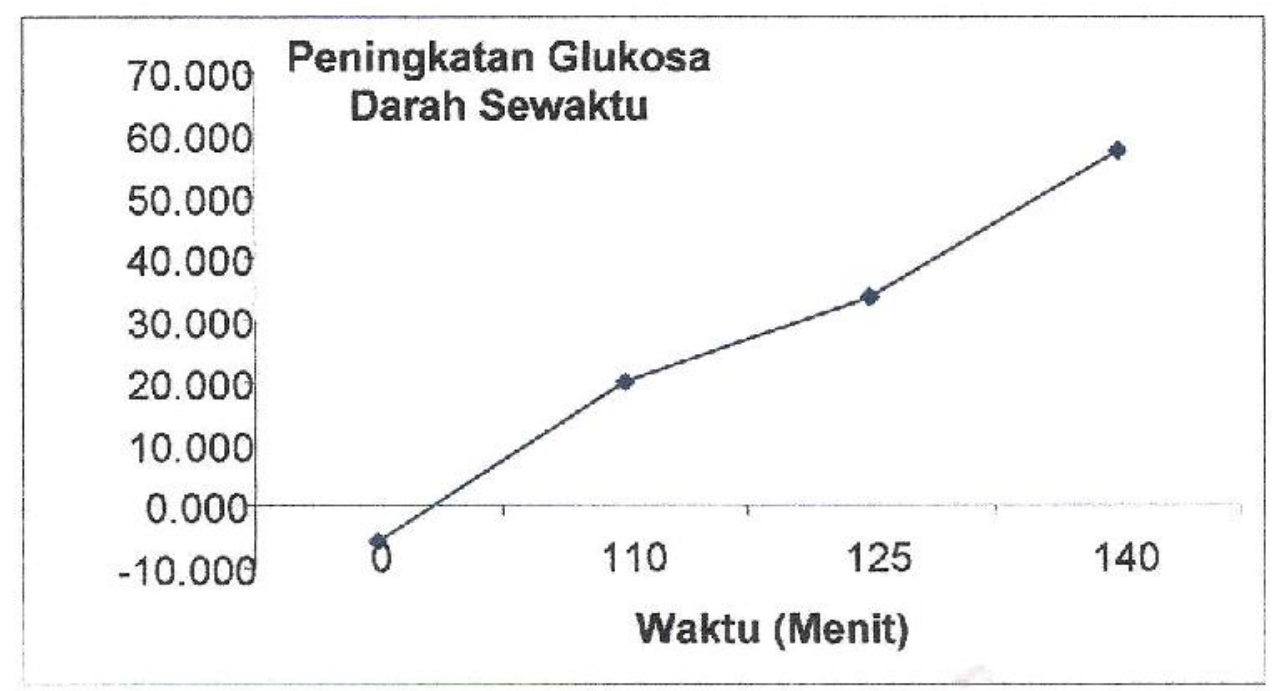

Berdasarkan plot respon (mean effect) tersebut dapat dibentuk urutan dari perlakuan waktu kebisingan dengan rata-rata gula darah yang paling tinggi sampai rata-rata yang paling rendah, sebagai berikut : kebisingan dengan lama 140 menit (mean $=57.333$ ) menunjukkan rata-rata gula darah yang tinggi kemudian diikuti kebisingan 125 menit (mean $=33.833$ ), kebisingan 110 menit (mean $=20.00)$, dan yang menunjukkan rata-rata gula darah yang paling rendah adalah kontrol (mean $=5.833$ ).

\section{Hasil analisis of variance (ANOVA)}

Berdasarkan pada hasil analisis ANOVA di dapatkan bahwa nilai $F$ dihitung sebesar 10.963 dengaan tingkat kemaknaan (p) 0,000 dan F tabel sebesar 3,098. Karena nilai $\mathrm{p}<0.05$ dan F hitung $>$ F tabel, maka terdapat perbedaan lama paparan kebisingan terhadap peningkatan kadar glukosa darah sewaktu yang signifikan antara perlakuan

Setelah pengujian dengan ANOVA menyatakan terdapat perbedaan lama paparan kebisingan yang bermakna kemudian dilakukan analisa Post Hoc Tests untuk mengetahui perbedaan lama paparan tiap-tiap kelompok, hasilnya menunjukkan adanya perbedaan nilai rata-rata antara kelompok 1 (kontrol) dengan kelompok 3, kelompok 1 dengan kelompok 4 dan kelompok 2 dengan kelompok 4

\section{Hasil uji korelasi dan regresi}

Pada hasil uji korelasi dan regresi linier sederhana, diperoleh nilai korelasi antara lama waktu kebisingan dengan peningkatan kadar glukosa darah sewaktu sebesar 0,716 dengan nilai signifikansi (p) sebesar 0,000 yang lebih kecil 0.05. Hal ini berarti bahwa terdapat hubungan yang bermakna positif antara pemberian lama kebisingan dengan peningkatan kadar glukosa darah sewaktu. Artinya peningkatan lama kebisingan akan meningkatkan glukosa darah sewaktu secara signifikan.

Untuk mengetahui pengaruh lama kebisingan terhadap kadar glukosa darah sewaktu, dapat diketahui dengan menggunakan analisa bentuk hubungan (regresi), karena dari uji korelasi belum menjelaskan hal tersebut.

Berdasarkan hasil pengujian dengan menggunakan analisa regresi linier sederhana, maka diperoleh hasil $\mathrm{R}^{2}$ (koefisien determinasi) sebesar 0,513 artinya bahwa $51,3 \%$ variabel peningkatan kadar glukosa darah sewaktu akan dipengaruhi oleh kebisingan dengan persamaan regresi linier sederhana , $\mathrm{Y}=-8.958+0,376 \mathrm{X}$. 
$76 \quad$ Vol. 7 No. 15 Desember 2011

Hasil penelitian mengenai pengaruh pemberian kebisingan terhadap peningkatan kadar glukosa darah sewaktu dapat ditunjukkan dalam grafik liniertas berikut:

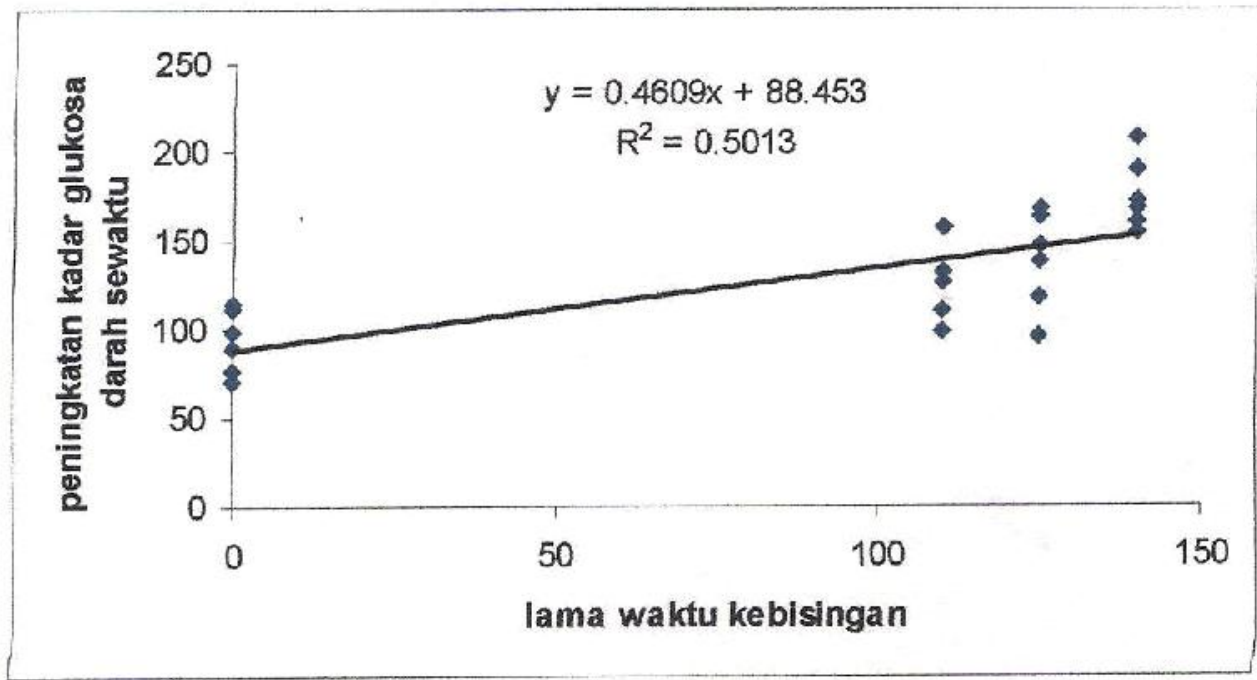

Gambar regresi Linier sederhana dari lama waktu paparan kebisingan

Berdasarkan grafik diatas terlihat garis regresi mengarah kekanan atas. Hal ini membuktikan adanya linieritas dari paparan kebisingan yang berpengaruh signifikan terhadap pengingkatan kadar glukosa darah sewaktu. Hal ini diperkuat dengan hasil koefisien korelasi untuk paparan kebisingan terhadap peningkatan kadar glukosa darah sewaktu yaitu sebesar 0,716 yang menunjukkan arah positif, artinya semakin lama waktu paparan kebisingan ternyata mampu meningkatkan kadar glukosa darah.

\section{PEMBAHASAN}

Penelitian ini bertujuan untuk membuktikan adanya perbedaan lama paparan kebisingan pada peningkatan kadar glukosa darah sewaktu dan membuktikan hubungan lama paparan kebisingan $90 \mathrm{~dB}$ dengan peningkatan kadar glukosa darah sewaktu pada mencit jantan.

Pada penelitian ini kebisingan $90 \mathrm{~dB}$ dipaparkan pada tiga kelompok, yaitu kelompok pertama dipapar selama 110 menit, kelompok kedua dipapar selama 125 menit dan kelompok ketiga dipapar selama 140 menit, serta satu kelompok kontrol ( tanpa paparan bising) Penetapan lama paparan selama 110 menit berdasarkan intensitas bunyi dan waktu paparan yang diperkenankan, sesuai dengan Departemen Tenaga Kerja 1994-1995.
Pada hasil penelitian ini terdapat perbedaan lama paparan kebisingan pada peningkatan kadar glukosa darah sewaktu mencit jantan $(p=0,000)$. Perbedaan lama paparan yang signifikan terjadi pada kelompok kontrol dengan kelompok 2, kelompok kontrol dengan kelompok 3 dan kelompok 1 dengan kelompok 3. Peningkatan signifikan kadar glukosa darah dimulai pada kelompok 3 (lama paparan 125 menit) jika dibandingkan dengan kelompok yang memiliki beda lama paparan 30 menit yaitu kelompok 2 (lama paparan 110 menit) dengan kelompok 4 (lama paparan 140 menit). Sedangkan perbedaan yang tidak signifikan terjadi pada kelompok yang memiliki beda lama paparan 15 menit yaitu antara kelompok 2 dan kelompok 3 dan kelompok 3 dengan kelompok 4. Meskipun tidak terdapat perbedaan yang signifikan antara kelompok yang memiliki beda lama paparan 15 menit, grafik plot effect menunjukkan kecenderungan peningkatan glukosa darah sewaktu.

Hasil penelitian dan analisa data membuktikan bahwa terdapat hubungan lama paparan kebisingan intensitas $90 \mathrm{Db}$ selama 110 menit, 125 menit, dan 140 menit dengan peningkatan kadar glukosa darah sewaktu pada mencit (Musmusculus) jantan ( $\left.\mathrm{p}=0.000, \mathrm{R}^{2}=0.513\right)$. hal ini sesuai dengan penelitian terdahulu yang 
membuktikan peningkatan kadar glukosa darah sewaktu pada 9 tentara sukarelawan yang mendapat paparan mesin jet turbo dengan intensistas $120 \mathrm{~dB}$, yaitu dari $82 \mathrm{mg} / \mathrm{dl}$ menjadi $106 \mathrm{mg} / \mathrm{dl}$ (Finkel, Poppen,1948).

Peningkatan glukosa darah ini dapat dijelaskan melalui peran hormon stres baik pada studi literatur maupun penelitian klinis. Peningkatan glukosa darah dapat terjadi akibat efek kumulatif dari kebisingan yang berulang (Novi,2004). Hal ini disebabkan oleh akumulasi hormon stress kortisol dalam tubuh (Spreng, 2002). Studi klinis pada 75 penderita psycosomatis kronis menunjukkan peningkatan signifikan kadar kortisol dan kadar glukosa darah dibandingkan dengan 50 kelompok kontrol (Mishira, Pandey, Sing, 2007). Pada studi cross sectional 112 pria yang terpapar bising 92-96 $\mathrm{dB}$ dilingkungan kerja menemukan peningkatan hormon stres pada darah yaitu kortisol, epileneprin dan norepineprin (Babisch,2003). Hormon stres noradrenalin berperan dalam peningkatan glukosa darah melalui penurunan sekresi insulin dan glikogenolisis, sedangkan adrenalin melalui proses glukoneogenesis dan glikogenosis. Hormon stres kortisol akan meningkatkan kadar glukosa darah melalui glikogenolisis dan penurunan penggunaan glukosa oleh sel (Babisch, 2003).

Pada penelitian ini dapat membuktikan konsep stres sel yang disebabkan oleh kebisingan lewat jalur aksis HPA dan sistem saraf simpatis dapat meningkatkan kadar glukosa darah sewaktu. Peningkatan aktivitas HPA aksis oleh stresor menyebabkan pelepasan kortisol yang akan meningkatkan kadar glukosa darah melelui glikogenolisis dan penurunan penggunaan glukosa oleh sel. Peningkatan aktivitas sistem saraf simpatis oleh stresor akan meningkatkan katekolmin dalam plasma dan jaringan yaitu noradrenalin pada ujung saraf simpatis dan sekresi hormon adrenalin dari sel kromafin di medula adrenal. Noradrenalin berperan dalam peningkatan glukosa darah melalui penurunan sekresi insulin dan glikogenolisis, sedangkan adrenalin melalui proses glukoneogenesis dan glikogenolisis.

Pada kelompok kontrol terdapat penurunan dan peningkatan kadar glukosa darah antara pemeriksaan pre-test dan post-test. Penurunan kadar glukosa darah diduga karena tidak adanya bising yang menyebabkan peningkatan aktivitas sistem neuroendokrin. Sedangkan peningkatan kadar glukosa adarah diduga akibat gelombang bunyi yang merambat ke dalam kelompok mencit kontrol, karena hal tersebut akan mempengaruhi keadaan stres mencit tersebut.

\section{KESIMPULAN}

Pada penelitian ini, maka dapat disimpulkan bahwa

1. Ada hubungan lama paparan kebisingan 90 dB selama 110 menit, 125 menit, dan 140 menit dengan peningkatan kadar glukosa darah sewaktu pada mencit (Mus musculus) jantan.

2. Ada perbedaan lama paparan kebisingan intensitas $90 \mathrm{~dB}$ pada peningkatan kadar glukosa darah suatu mencit (Mus musculus) jantan.

\section{KEPUSTAKAAN}

Babisch, W.2003. Stress Hormone In The Research on Cardiovascular Effect of Noise. Berlin: Division of Environment and Health, Federal Enviroment Agency.

Finkel, A.L and Poppen, J.R. 1948. Clinical Effect of Noise and Mechanical Vibrations of a Turbo jet on Man. Journal Applied Physiology.

Guyton and Hall. 1997. Buku Ajar Fisiologi Kedokteran. Jakarta: Penerbit buku Kedokteran EGC. H 1209-1219

Lang, F. 2000. Hormones Dalam Color Atlas of Pathophysiology.New York: thieme New

York. h. 264-270

Mishira, K.K., Pandey, H.P., Sing, R.H.2007. Clinical Study On Cortisol and Certain Metabolites

In Some Chonic Psychosomatic Disorders.Indian Journal of Clinical Biochemistry.

Novi, A. 2004. Pengaruh Kebisingan terhadap Kesehatan Tenaga Kerja. Cermin Dunia Kedokteran. h 24-28

Roestam, A.W.2004.Program Konservasi Pendengaran di Tempat Kerja. Cermin Dunia Kedokteran. h 29-33

Spreng, M. 2002. Possible Health Effect of Noise Induce Cortisol Increase. Germany : Physiology and Experimental Pathophysiology Department. University of Erlangen 


\section{$78 \quad$ Vol. 7 No. 15 Desember 2011}

Stephens, D. , Rood, G.1978. The Non Auditory Effect of Noise on Health Hand Book of Noise assessment. New York: Environmental Engineering Company.

World Health Organization.1995.Deteksi Dini Penyakit Akibat Kerja. Jakarta. Penerbit Buku Kedokteran EGC. 